\title{
An Uncommon Acute Abdomen Cause Mimicking Acute Appendicitis: Caecal Diverticulitis, A Case Report
}

\author{
Akut Apandisiti Taklit Eden Yaygın Olmayan Bir Akut Karın Nedeni: \\ Çekal Divertikülit, Bir Olgu Sunumu
}

Tufan Elipek

Edirne Devlet Hastanesi, Genel Cerrahi Kliniği, Edirne

\begin{abstract}
Solitary caecal diverticulitis is an uncommon clinical situation. Its diagnosis is difficult expect surgical assessment. It appears to have the similar manner of acute appendicitis, generally. The case in this study is a patient has operated for prediagnosis of acute appendicitis because of the having right iliac fossa pain, nausea and vomiting which are common symptoms of acute appendicitis, but in her exploration it was determined to have caecal mass.
\end{abstract}

Keywords: Caecal diverticulitis; acute appendicitis; right-sided colonic diverticulitis

Aplication: 09.02.2012

Accepted: 23.03 .2012

\section{Özet}

Soliter çekal divertikülit yaygın olmayan bir klinik durumdur. Cerrahi müdahale dışında tanısı zordur. Genellikle akut apandisit benzeri bulgularla ortaya çıkar. Bu çalışmadaki olgu, karın sağ alt kadran ağrısı, bulantı ve kusma nedeniyle acil servisimize başvuran, akut apandisit ön tanısı acil şartlarda opere edilen, ancak eksplorasyonda çekal kitle saptanan bir hastadır.

Anahtar Kelimeler: Çekal divertikülit; akut apandisit; sağ kolon divertiküliti

Başvuru Tarihi: 09.02.2012 Kabul Tarihi: 23.03.2012

\section{Introduction}

Caecal diverticulitis has unclear ethiology, still. A true solitary diverticulum which is more uncommon situation contains all layers of the bowel wall. ${ }^{1}$ Because of caecal diverticulitis can mimic all signs of acute appendicitis, the preoperative diagnosis of caecal diverticulitis is extremely difficult. ${ }^{1,2}$ Therefore, the diagnosis to distinguish is usually made in the operating room. ${ }^{2}$

It is known that a lot of views on the most optimal and appropriate management for caecal diverticulitis or symptomatic solitary caecal diverticulum. In some studies, a wedge resection of the diverticulum, ileo-caecal resection or right hemicolectomy has been suggested as a conservative approach. ${ }^{3,4}$

In the present study, similar clinical presentations, diagnosis and treatment methods of caecal diverticulitis and acute appendicitis have been reviewed according to literatures. 


\section{Case Report}

A female patient, 32 years old. In July 2010, she administrated to emergency department because of having right iliac fossa pain, nausea and vomiting during 2 days. She had $37.6{ }^{\circ} \mathrm{C}$ fewer, pulse 72 / minute, and blood pressure 120/80 $\mathrm{mmHg}$. In physical examination her bowel sounds were hypoactive. Sensitivity, muscular defence and rebound tenderness at her right iliac fossa were present. It was observed that the values of WBC: 13.100/mL, hemoglobin: $14.8 \mathrm{~g} / \mathrm{dL}$, Plt: $331000 / \mathrm{mL}$, urinary tests; 5-6 epithelial cell, 1-2 leucocytes. In abdominal $x$-ray it was observed appropriate view with caecal level in right iliac fossa. Therefore, the patient operated for prediagnosis of acute appendicitis. In the operation, it was observed appendix was normal but there was a caecal mass about $3 \times 3 \mathrm{~cm}$ on caecum lateral wall (Figure 1). Malignancy had not been exclude because of the operation was made under emergency conditions. Therefore, the patient was operated by right hemicolectomy and end to side ileotransversostomy. In postoperative $6^{\text {th }}$ day, the patient was discharged, without complications. The pathology result belonging the patient was reported as appropriate with caecal diverticulitis (Figure 2).

Figure 1: The caecal mass on caecum lateral wall

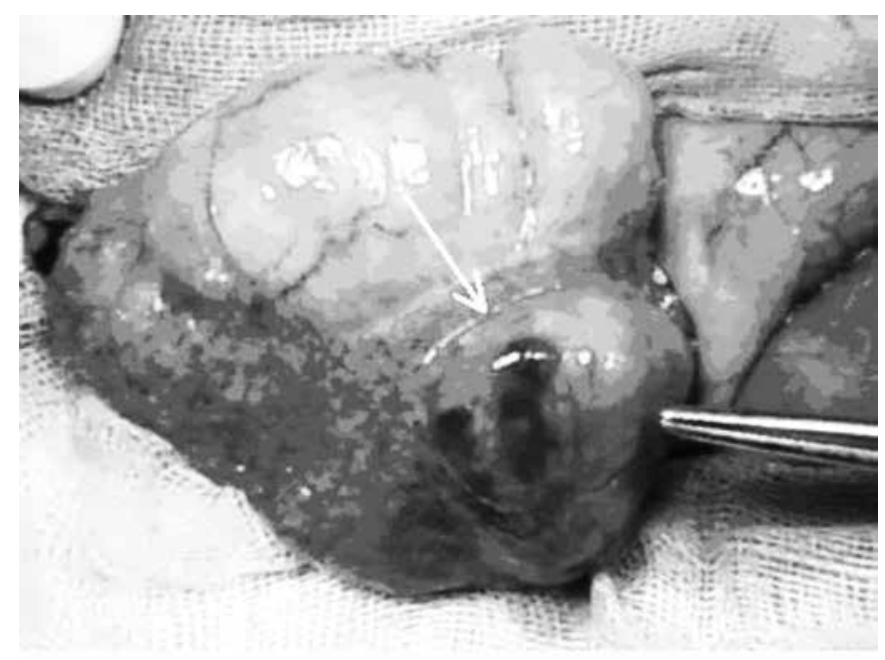

\section{Discussion}

It is reported that caecal diverticulitis has been described by Potier in $1912 .{ }^{5}$ Also, it is indicated similar cases much more than 1000 in literatures and their incidence changes between $1 / 50-1 / 300$ that of appendicitis. ${ }^{5}$

Figure 2: The histopathological view of the caecal diverticulitis

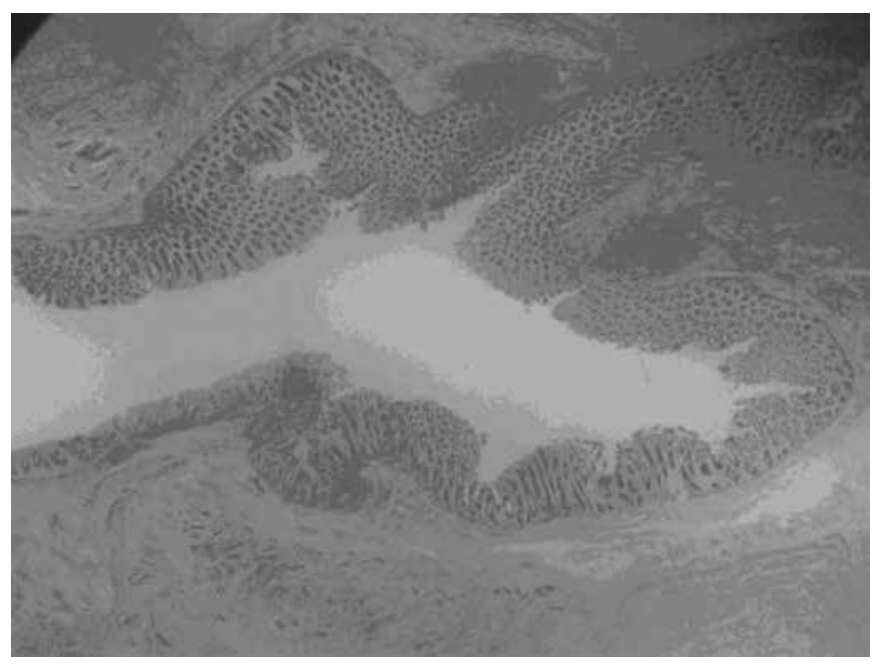

Solitary caecal diverticulitis is similar to other diverticulum with their presentations of inflammation, perforation or bleeding. It is informed that its diagnosis is similar to acute appendicitis with right iliac fossa pain, vomiting and occasional nausea. ${ }^{6}$ Also, we observed similar diagnosis in our case.

Acute appendicitis is a clinical diagnosis, mainly. Preoperative radiological investigations are usually not subjected for many patients presenting with right iliac fossa pain and tenderness with a presumptive diagnosis of appendicitis except where a mass is palpable and a caecal carcinoma is suspected. ${ }^{2}$ Also, preoperative radiological investigations were not performed in the patient in this case because of similar presents and under emergency conditions.

The scans of computerized tomography and abdominal ultrasonography can show high diagnostic accuracy. Therefore, they may play a very important role in the diagnosis of the illness, preoperatively. ${ }^{1,8,9}$ Chou at al 8 investigated a total of 934 patients with caecal diverticulitis having right iliac fossa pain. They have reported a sensitivity of $91.3 \%$ and a specificity of $99.5 \%$, accuracy of $99.5 \%$ in the diagnosis of caecal diverticulitis 
with abdominal ultrasonography. In various studies, it is shown that accuracy rate of distinguishing acute appendicitis from caecal diverticulitis with CT scan in perioperative period is $98 \%$ in sensitivity and specificity. ${ }^{7-9}$

In recent years, it has been shown that the magnetic resonance imaging is useful method diagnosis of right sided diverticulitis. Especially for the patients who have equivocal ultrasonography features or the patients who they must avoid from ionising radiation likewise young or pregnant patients, the magnetic resonance may be useful method. ${ }^{9}$

Surgical treatment of non-perforated caecal diverticulitis is discussed. Surgical resection ranges can show variation as an isolated diverticulectomy, ileocaecal resection or standard right hemicolectomy. It has been described laparoscopic diverticulectomy to manage of right sided diverticulitis. ${ }^{10}$ In a study which was performed by Lane et al 4 , it was reported $40 \%$ of 49 patients treated with diverticulectomy or antibiotics only, required subsequent

\section{References}

1. Karatepe O, Gulcicek OB, Adas G, Battal M, Ozdenkaya Y, Kurtulus I, et al. Caecal diverticulitis mimicking acute Appendicitis: a report of 4 cases. World J Emerg Surg 2008;3:16

2. Cole M, Ayantunde AA, Payne J. Caecal diverticulitis presenting as acute appendicitis: a case report. World J Emerg Surg 2009;4:29.

3. Poon RT, Chu KW. Inflammatory caecal masses in patients presenting with appendicitis. World J Surg 1999;23(7):713-716.

4. Lane JS, Sarkar R, Schmit PJ, Chandler CF, Thompson JE Jr. Surgical approach to caecal diverticulitis. J Am Coll Surg 1999:188(6):629-634.

5. Connolly D, McGookin RR, Gidwani A, Brown MG. Inflamed solitary caecal diverticulum - it is not appendicitis, what should I do? Ann R Coll Surg Engl 2006;88(7):672-674.

6. Sardi A, Gokli A, Singer JA. Diverticular disease of the caecum and hemicolectomy by an on-going inflammatory process. Right hemicolectomy has always risk of high morbidity and mortality. But, where to make diverticulectomy is impossible or when to suspect risk of a carcinoma, right hemicolectomy should be performed to adequate lymphovascular clearance. ${ }^{4,9,10}$

In this case, it was treated standard right hemicolectomy because of the findings of inflammatory mass within caecum and malignancy possibility could not be ignored.

\section{Conclusion}

Caecal diverticulitis is shown rare clinically. It can be determined peroperatively in the patients which operated for acute appendicitis because of the having right iliac fossa pain. In surgical treatment, although there are some choices such as diverticulectomy and ileocaecal resection, right hemicolectomy can be used in the situation which malignancy possibility can not be ignored such as in this case.

ascending colon. A review of 881 cases. Am Surg 1987;53(1):4145 .

7. Jang HJ, Lim HK, Lee SJ, Lee WJ, Kim EY, Kim SH. Acute diverticulitis of the caecum and ascending colon: the value of thinsection helical CT findings in excluding colonic carcinoma. AJR Am J Roentgenol 2000;174(5):1397-1402.

8. Chou YH, Chiou HJ, Tiu CM, Chen JD, Hsu CC, Lee CH, et al. Sonography of acute right side colonic diverticulitis. Am J Surg 2001;181(2):122-127.

9. Cobben LP, Groot I, Blickman JG, Puylaert JB. Right colonic diverticulitis: MR appearance. Abdom Imaging 2003;28(6):794-798.

10. Pelosi MA 3rd, Pelosi MA, Villalona E. Right-sided colonic diverticulitis mimicking acute cholecystitis in pregnancy: case report and laparoscopic treatment. Surg Laparosc Endosc 1999;9(1):63-67. 